\title{
Nucleotide Sequence and Functional Analysis of the Two nifH Copies of Rhizobium ORS571
}

\author{
By FRANÇOISE NOREL AND CLAUDINE ELMERICH* \\ Unité de Physiologie Cellulaire, Département des Biotechnologies, Institut Pasteur, \\ 28 Rue du Dr Roux, 75724 Paris Cedex 15, France
}

(Received 25 September 1986; revised 24 November 1986)

\begin{abstract}
In Rhizobium ORS571, which is able to form both root and stem nodules on the tropical plant Sesbania rostrata and to grow in the free-living state at the expense of $\mathrm{N}_{2}$, two copies of the nifH gene, which codes for the nitrogenase Fe-protein, were characterized. One copy, nifHI, was localized in the nifHDK operon; the other, nifH2, was localized elsewhere. nifHI and nifH2 differed in only six nucleotides and both encoded a polypeptide of 296 amino acids with a single change at position 282, a serine in nifHl and a threonine in nifH2. At position 102, arginine in the sequence Gly-Arg-Gly-Val-Ile-Thr might, as in Rhodospirillum rubrum, be the site of 'switchoff' inactivation. Compared with other nifH genes, the highest $S_{\mathrm{AB}}$ was found with Bradyrhizobium japonicum and Rhizobium sp. (Parasponia). A sequence identical (nifHI) or very similar (nifH2) to the nif consensus sequence was found upstream from the initiation codon. Homology with sequences upstream from Klebsiella pneumoniae nif promoters, which affect nif $A$ mediated activation, was also found in both cases. From mutants carrying either a single nifHI or nifH 2 deletion, or a double nifH1-nifH2 deletion, it appeared that both genes were functional ex planta and in planta and that no other nif $H$ copy seemed to be present in ORS571. The optimal expression of nifHI and of nifH2 might depend on different physiological conditions.
\end{abstract}

\section{INTRODUCTION}

The fast-growing Rhizobium strain ORS571, isolated from stem nodules of the tropical legume Sesbania rostrata, forms nodules on both stems and roots of the host plant (Dreyfus \& Dommergues, 1981) and can grow in the free-living state at the expense of $\mathrm{N}_{2}$ as the sole nitrogen source (Elmerich et al., 1982; Dreyfus et al., 1983). The nitrogenase complex that catalyses the reduction of $\mathrm{N}_{2}$ to $\mathrm{NH}_{3}$ has been isolated from a variety of diazotrophs (Eady \& Smith, 1979) including Rhizobium ORS571 (Kush et al., 1985). The nitrogenase of Rhizobium ORS571 was subject to 'switch-off' when ammonia was added to a $\mathrm{N}_{2}$-fixing culture (Kush et al., 1985). In all cases, nitrogenase was shown to be composed of two protein components, a MoFe-protein (component I) and an Fe-protein (component II). The MoFe-protein is a tetramer composed of two non-identical subunits $(\alpha$ and $\beta$ ) and the Fe-protein is a dimer composed of two identical subunits (Eady \& Smith, 1979). In a few cases, the complete or partial amino acid sequence of both proteins has been determined (Tanaka et al., 1977; Hausinger \& Howard, 1982; Hase et al., 1984). Moreover, nitrogenase isolated from various organisms shows a remarkable similarity in component composition and the formation of active heterologous complexes has been reported (Emerich \& Burris, 1978). The genes coding for the nitrogenase polypeptides (nifHDK) were initially characterized in Klebsiella pneumoniae, where they are organized in a single transcription unit (Elmerich et al., 1978; Merrick et al., 1978). The nifH gene encodes the two identical subunits of component II whereas nifD and nifK encode the $\alpha$ and $\beta$ subunits of component $\mathrm{I}$, respectively. As shown by hybridization with $K$. pneumoniae nif

Abbreviation: ORF, open reading frame. 
probes, the nifHDK genes, in particular nifH, are highly conserved among different genera of diazotrophs (Ruvkun \& Ausubel, 1980; Mazur et al., 1980). This facilitated identification and cloning of the structural genes for nitrogenase from a variety of $\mathrm{N}_{2}$ fixers including bacteria of the genus Rhizobium (Hennecke, 1981; Elmerich et al., 1982; Quinto et al., 1982; Scott et al., 1982; Downie et al., 1983; Scott et al., 1983a, b; Fuhrmann \& Hennecke, 1984). In Rhizobium ORS571, identification and cloning of DNA fragments homologous to $K$. pneumoniae nifH, $D, K$ and $E$ were previously reported (Elmerich et al., 1982; Norel et al., 1985a; Donald et al., 1986). By site-directed mutagenesis, it was shown that these genes are organized in two independent transcription units, nifHDK and nifE (Donald et al., 1986; Denèfle et al., 1987). The nucleotide sequence of nifH from ten eubacteria and from a methanogenic archaebacterium is now established: Anabaena 7120 (Mevarech et al., 1980), K. pneumoniae (Scott et al., 1981; Sundaresan \& Ausubel, 1981), R. meliloti (Torök \& Kondorosi, 1981), Rhizobium sp. (Parasponia) (Scott et al., 1983a), R. trifolii (Scott et al., 1983b), Bradyrhizobium japonicum (Fuhrmann \& Hennecke, 1984), Azotobacter vinelandii (Brigle et al., 1985), Rhizobium phaseoli (Quinto et al., 1985), Clostridium pasteurianum (Chen et al., 1986), Azotobacter chroococcum (Robson et al., 1986) and Methanococcus voltae (Souillard \& Sibold, 1986). From these results, nifH appears as the most conserved translated gene in bacteria. Another interesting feature of $n i f H$ is the presence of multiple copies of the gene in several diazotrophs including $R$. phaseoli (Quinto et al., 1982), Anabaena 7120 (Rice et al., 1982), B. japonicum (Prakash \& Atherly, 1984), Calothrix sp. (Kallas et al., 1983), Rhodopseudomonas capsulata (Scolnik \& Haselkorn, 1984), Azotobacter chroococcum (Robson et al., 1986), C. pasteurianum (Chen et al., 1986), and Rhizobium ORS571 (Norel et al., 1985a, b; Donald et al., 1986). A functional analysis of the reiterated copies was done in Rps. capsulata (Scolnik \& Haselkorn, 1984), R. phaseoli (Quinto et al., 1985), and Azotobacter chroococcum (Robson et al., 1986).

Because of the unusual properties of strain ORS571, forming both root and stem nodules, fixing $\mathrm{N}_{2}$ under both free-living and symbiotic conditions and having a nitrogenase subject to 'switch-off' by inactivation of component II, we decided to determine the nucleotide sequence of the two nif $H$ copies and to study their expression. Results reported here show that the two copies are almost identical, closely related to nifH of B. japonicum (Fuhrmann \& Hennecke, 1984) and of Rhizobium sp. (Parasponia) (Scott et al., 1983a), and that they are functional both $e x$ planta and in planta.

\section{METHODS}

Bacterial strains, bacteriophages, plasmids and growth conditions. Bacterial strains and bacteriophages are listed in Table 1. Rhizobium strains were grown as described by Elmerich et al. (1982). Escherichia coli strains were grown in Luria Broth medium (Maniatis et al., 1982). The final concentrations of antibiotics for Rhizobium are indicated in Table 5; those for $E$. coli were $\left(\mu \mathrm{g} \mathrm{m}^{-1}\right)$ : carbenicillin, 100 ; chloramphenicol, 25 ; tetracycline, 5 ; kanamycin, 40 ; gentamicin, 20; spectinomycin, 25. Carbenicillin was used to select the Amp ${ }^{R}$ phenotype. Plasmids are listed in Table 1 or described in Fig. 1. Plasmids containing $K$. pneumoniae nif genes were previously described (Norel et al., 1985a) and are not listed in Table 1. Plasmid pRK2013 was used to mobilize IncP Tra ${ }^{-}$plasmids. Marker exchange in ORS571 was done using PPH1JI and R751 as described by Denèfle et al. (1987). The cloning vector pHE3 and the methods for direct selection of recombinant DNA in $E$. coli RR28 were previously described (Hennecke et al., 1982).

Molecular biology techniques. DNA isolation, endonuclease digestion, ligation, alkaline phosphatase and Bal31 treatment, filling-in of protruding ends, DNA transformation, nick translation, nitrocellulose filter hybridization, and colony hybridization were done essentially as described by Maniatis et al. (1982). DNA sequencing was done by the method of Sanger et al. (1977) with phage M13 derivatives (Messing \& Vieira, 1982) that were propagated in $E$. coli TGl. Sequence data were compiled by computer analysis by using the program devised by Staden (1983). To prepare a $\mathrm{Sp}^{\mathrm{R}}$ cartridge with $S a I I-S m a I$ extremities, a $3.4 \mathrm{~kb}$ BamHI fragment from pGV764 containing the $\mathrm{Sp}^{\mathrm{R}}$ gene was cloned into $\mathrm{pUC9}$ to yield $\mathrm{pPC} 942$. From this plasmid, the $S a I-S m a I$ fragment containing the $\mathrm{Sp}^{\mathrm{R}}$ gene was recovered.

Plant test and nitrogenase assay. Root inoculation of Sesbania rostrata plantlets and nitrogenase assays were done as described by Elmerich et al. (1982). 
Table 1. Bacterial strains, bacteriophages and plasmids

Relevant properties

Escherichia coli
RR28
MC1061
TG1
HB101
Rhizobium ORS571
Wild strain
57182
57171
57172
Bacteriophages
M13mp8
M13mp9

Plasmids
pUC8
pUC9
pHE3
pBR322: :Tn5
pLA29-27
pRK2013
pPH1JI
R751
pGV764
pPC942
pRS2
pRS82

leu thi pro pheS12 recA $\mathrm{r}^{-} \mathrm{m}^{-}$ araD139 $\Delta($ ara-leu $) 7697$ rpsL galU galK $\triangle($ lacIPOZY $) X 74$

$\Lambda($ lac-pro) supE thi hsdD5/F'traD36 lac $P^{\circ}$ alacZM15

leu thi pro hsdR recA rpsL

$\triangle$ nifHI $\mathrm{Km}^{\mathrm{R}}(\mathrm{pPH} \mid \mathrm{JI})$

AnifH2 $\mathrm{Sp}^{\mathbb{R}}(\mathrm{R} 751)$

$\Delta n i f H 2 \mathrm{Sp}^{\mathrm{R}} \Delta$ nifHI $\mathrm{Km}^{\mathrm{R}}(\mathrm{pPH} I \mathrm{JI})$

$\mathrm{Lac}^{+}$

$\mathrm{Lac}^{+}$

Vector or

replicon

pBR322

pBR322

pACYC184

pBR322

RK2

ColEl

pBR325

PUC9

pBR322

PRK290

$\mathrm{Ap}^{\mathrm{R}} \mathrm{Lac}^{+}$

$\mathrm{Ap}^{\mathrm{R}} \mathrm{Lac}^{+}$

IncP $\mathrm{Tc}^{R} \mathrm{Km}^{\mathrm{R}} \mathrm{Tra}^{-}$

IncP $\mathrm{Km}^{\mathrm{R}} \mathrm{Tra}^{+}$

IncP $\mathrm{Gm}^{\mathrm{R}} \mathrm{Tra}^{+}$

IncP $\mathrm{Tp}^{R} \mathrm{Tra}^{+}$

Source of the $\mathrm{Sp}^{\mathrm{R}}$ gene

$A^{R}$ (see Fig. 1)

$\mathrm{Tc}^{\mathrm{R}} \mathrm{Km}^{\mathrm{R}}$ (see Fig. 1)
Reference

Hennecke et al. (1982)

Casadaban et al. (1980)

Wain-Hobson et al. (1985)

Elmerich et al. (1982)

Dreyfus \& Dommergues (1981)

Denèfle et al. (1987)

This work

This work

Vieira \& Messing (1982)

Vieira \& Messing (1982)

References

Relevant properties

\begin{tabular}{|c|}
\hline 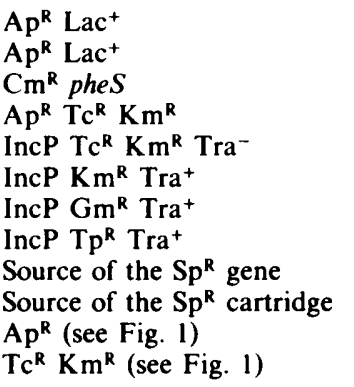 \\
\hline
\end{tabular}

\author{
Vieira \& Messing (1982) \\ Vieira \& Messing (1982) \\ Hennecke et al. (1982) \\ This laboratory \\ Allen \& Hanson (1985) \\ Figurski \& Helinski (1979) \\ Hirsch \& Beringer (1984) \\ Jobanputra \& Datta (1974) \\ R. Deblaere, Bruxelles \\ This work \\ Elmerich et al. (1982) \\ Denèfle et al. (1987)
}

\section{RESULTS AND DISCUSSION}

\section{Cloning of the second copy of nifH}

Hybridization, with a nifH intragenic probe prepared from $K$. pneumoniae or $R$. phaseoli, of Rhizobium ORS571 total DNA digested with several restriction endonucleases revealed two fragments in most cases, except with Pst I where a single $9.5 \mathrm{~kb}$ fragment was detected (Norel et $a l ., 1985 a$ ). The same result was observed when the R1 fragment (Fig. 1), was used as a probe (Norel et al., 1985a). This suggested that in ORS571 the two nif $H$ copies were carried by two Pst I fragments of about the same size. The nif $H$ copy adjacent to nifDK will be referred to as nifHI and the second nifH copy as nifH2. To clone the Pst I fragments containing nifHI and nifH2, sizefractionated fragments (between 7 and $12 \mathrm{~kb}$ ) of ORS571 total DNA were ligated at the unique Pst I site of pHE3. Transformants were screened by colony hybridization using the R1 fragment as probe and recombinant plasmids containing a $9.5 \mathrm{~kb}$ Pst I DNA insert were analysed. The physical map of pRS68, which contains nifHI is shown in Fig. 1. Another plasmid, termed pRS54 (Fig. 1), appeared to carry nifH2. The localization of nifH2 in the insert was established by using the R1 fragment as a probe. Homology to R1 was limited to the $1.65 \mathrm{~kb}$ PstI-SmaI fragment and a strong homology was found within the $0.6 \mathrm{~kb}$ Xhol fragment (R2 in Fig. 1). The $\mathrm{R} 2$ fragment was used as a probe against pRS2 hydrolysed by $X h o \mathrm{I}$ and $\mathrm{BamHI}+\mathrm{XhoI}$. Only the $\mathrm{R} 1$ fragment hybridized with R2. Moreover, R1 and R2, when used as probes against OR571 total DNA restricted by several endonucleases, revealed hybridizing fragments of similar size (e.g. 13 and $16 \mathrm{~kb} \mathrm{BamHI}$ fragments, 7 and $20 \mathrm{~kb} \mathrm{Bg} / \mathrm{II}$ fragments, 2.8 and $20 \mathrm{~kb} S m a I$ fragments, a $0.6 \mathrm{~kb}$ XhoI fragment, and a $9.5 \mathrm{~kb}$ Pst I fragment) (data not shown). The restriction map of the insert carried by pRS54 (Fig. 1) was presented in a preliminary report (Norel et al., $1985 \mathrm{~b}$ ). The entire $9.5 \mathrm{~kb}$ Pst I fragment from pRS54 was used as a probe against plasmids carrying several nif genes of $K$. pneumoniae. No homology was detected except with nif $H$. We 
(a)
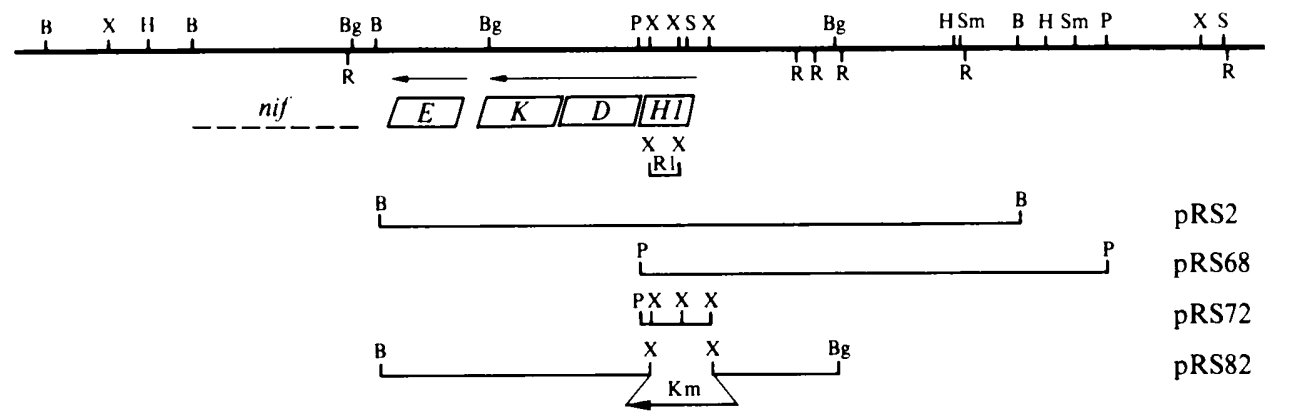

pRS2 pRS68 pRS72 pRS82

(b)

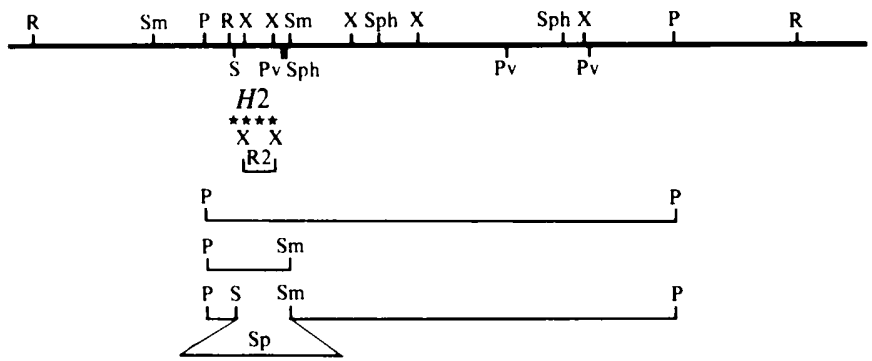

Fig. 1. Restriction map of Rhizobium ORS571 DNA fragments carrying the first copy of nifH (nifHI) in the nifHDKE cluster and the second copy of nifH (nifH2). (a) Physical map of the DNA region carrying the nifHDKE cluster. The localization of the nifHDKE genes and the direction of transcription (Norel $e t$ $a l ., 1985 a$ ) are indicated by boxes and arrows, respectively. The localization of the adjacent nif region is indicated by --- (Denèfle et al., 1987). Plasmids pRS2 and pRS82 were previously described (Elmerich et al., 1982; Denèfle et al., 1987). Plasmid pRS68 contained the $9.5 \mathrm{~kb}$ Pst I fragment cloned into pHE3. Plasmid pRS72, used as a source of DNA for sequencing, was constructed as follows. The $1 \mathrm{~kb}$ PstISall fragment carrying nifHl was cloned into pUC8 to yield pRS67 (not shown). The adjacent $0.5 \mathrm{~kb}$ $\mathrm{Sal}-\mathrm{XhoI}$ fragment was subsequently cloned at the $\mathrm{SaI}$ site of pRS67 in the correct orientation to yield pRS72. The R1 fragment was purified from pRS72. (b) Physical map of the DNA region containing nifH2 whose localization is indicated by 5-pointed stars. The $9.5 \mathrm{~kb}$ Pst I fragment was cloned into pHE3 and pLA29-17 to yield pRS54 and pRS55, respectively. The $1.65 \mathrm{~kb}$ PstI-SmaI fragment was cloned into pUC9 and pUC8 to yield pRS56 and pRS57 (not shown), respectively, which were used for sequencing. The R2 fragment was purified from pRS54. Plasmid pRS71 was constructed as follows. The $1.1 \mathrm{~kb}$ Sall-SmaI fragment of pRS54, which contained nifH2, was substituted by the $3.4 \mathrm{~kb}$ SalISmal fragment of pPC942, which contained a Sp ${ }^{\mathrm{R}}$ gene, to yield pRS66 (not shown). The deletion was subsequently transferred into pRS55, by homologous recombination between pRS55 and pRS66 in $E$. coli MC1061. Restriction sites: B, BamHI; Bg, BgIII; H, HindIII; P, PstI ; Pv, PvuI ; R, EcoRI ; S, SaII; Sph, SphI; Sm, SmaI; X, XhoI.

therefore assumed that no DNA sequence homologous to any nif gene of $K$. pneumoniae was located in the vicinity of nifH2. Plasmids pRS68 and pRS54 were both used as probes against ORS571 total DNA. This allowed us to establish or to corroborate the physical map of DNA fragments surrounding the probes (Fig. 1). Our data are in agreement with restriction maps of the two nifH regions of ORS571 also reported by Donald et al. (1986).

\section{DNA sequence analysis of the two nifH coding regions}

The complete nucleotide sequence of ORS571 nifHI and nifH 2 was established. Fig. 2 gives an outline of the sequencing strategy employed. About 1500 nucleotides were sequenced in each region.

Nucleotide sequence of nifHl. The orientation of nifHI was deduced from hybridization experiments (Norel et al., 1985a). Computer analysis of the three possible reading frames in both strands revealed a single frame large enough in the correct orientation to encode a nif $H$ 

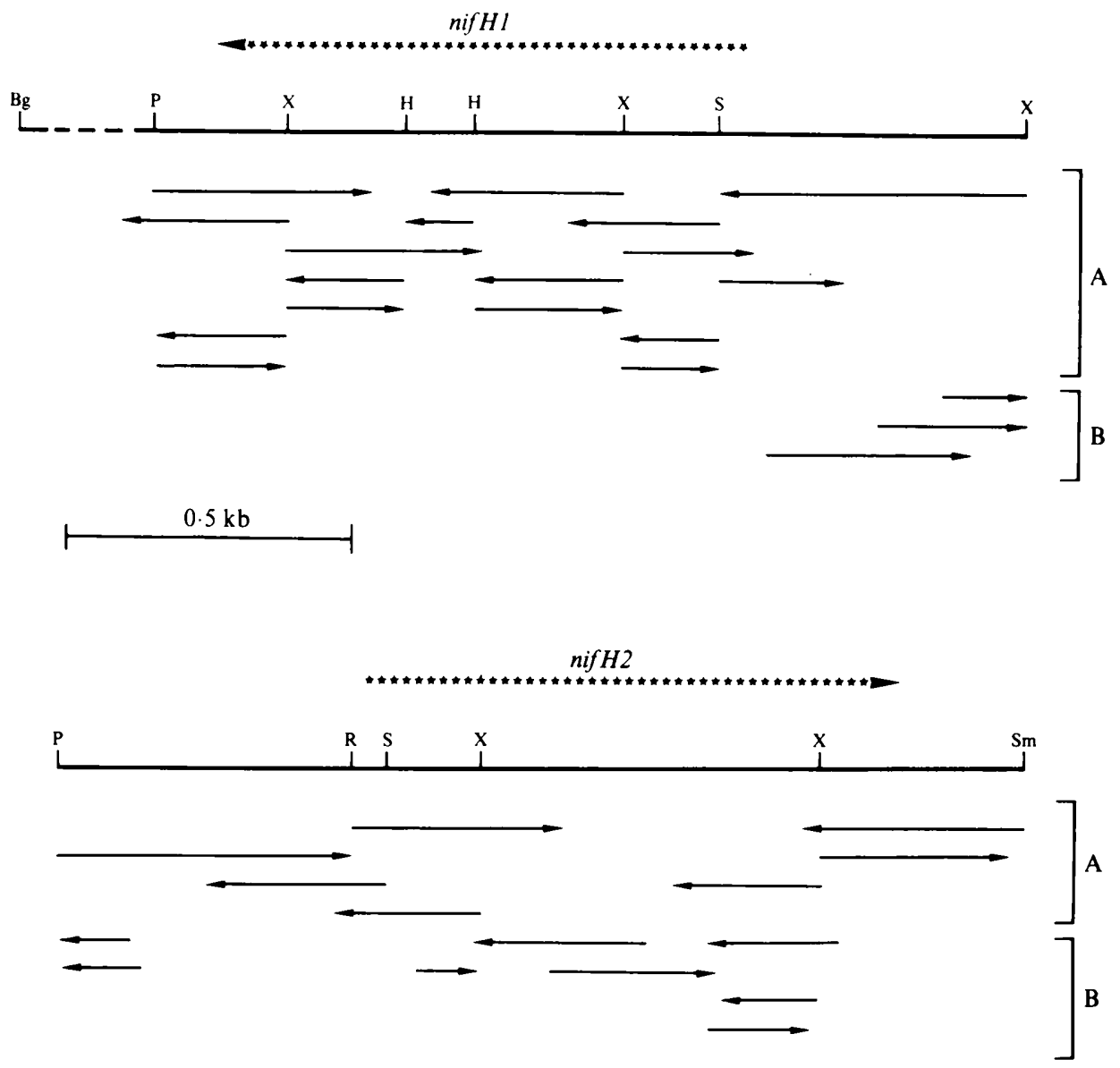

Fig. 2. Strategy used for sequencing Rhizobium ORS571 nifH genes. Arrows indicate direction and length of sequenced fragments. A, Sequences obtained after cloning nifHI restriction fragments from pRS2 and pRS72 and nifH2 restriction fragments from pRS54 and pRS56 into M13 derivatives. B, Fragments obtained after Bal31 treatment of pRS72 (nifHI) and pRS56(nifH2) and subcloning into M13 derivatives. Restriction sites as in Fig. 1. H, HaeIII. Stars indicate the extent and direction of transcription of the nifH genes.

polypeptide. The nucleotide sequence of nifHI and the predicted amino acid sequence are shown in Fig. 3. From the presumptive ATG start codon at position +1 to the TGA stop codon at position 889, an open reading frame (ORF) accounts for a polypeptide of 296 amino acids. Purified nitrogenase component II had an estimated $M_{\mathrm{r}}$ of 36000 and a pI of 5.3 (Kush et al., 1985). The $M_{\mathrm{r}}$ of the polypeptide deduced from the sequence is 31951 , thus slightly different from that of purified component II. The discrepancy between the two estimations may be due to the acidic nature of the polypeptide, which in SDS-PAGE migrates as a polypeptide with a higher apparent $M_{\mathrm{r}}$. As no other in-frame ATG was found upstream from the presumptive initiation codon and as the $M_{\mathrm{r}}$ matches with other nifH products (Eady \& Smith, 1979), we assumed that the identified ORF was the correct one. The sequence upstream from the start codon was determined for about $450 \mathrm{bp}$. A 5'-AGGAG-3' sequence, which is a potential ribosome-binding site (Shine \& Dalgarno, 1974), is located seven nucleotides upstream from the suggested initiation codon.

A second ORF, located downstream from nifHl, was found. This ORF starts with an ATG located in position 959 and is preceded by a $5^{\prime}$-AGGA-3' sequence eight nucleotides upstream from the potential initiation codon. The predicted amino acid sequence of this ORF is presented 
S'TC GAGCGTGGGC AGAGGGGTGA GGTCCACAM CGTCATCGCa TCCTCCAGCG CGGCCGGCGG CATCGCGCGG CGTCGCTGCA CCCMaCCMC S'TC GAGCGTGGGC AGAGGGGTGA GGTCCACAM CGTCATCGCA TCCTCCAGCG CGGCCGGCGG CATCGCGCG, CGTCGCTGCA CCCMUGCA
2 AAAGACGCGC CGCTGGTCCA CGGCCTTCGC GGTTTCGACA CCATCTGCA TGGCAGCCTC GCTCGATGCG GGCCCGCCG TTCCGTGGC CTCGCGTGM

$$
\text { 1350 } 0.300
$$

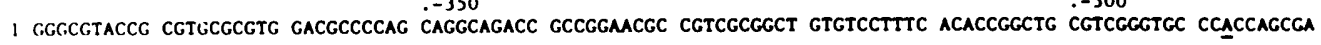

2 CCTSTTGCAM ATCCGTTCCG TGTTCCGGAC GCGGAGGTGG GCGATGATGa TCCCTTGCTT CGGCCCGCCG GTCCCTGCCG CAACCCGAGC GGäACGTG

I tgtcGCg.

2 ITTCCITTCC MACAGCCTGC GGCGTTCTGT CAGgITCGAG ACATGCCGTC CCCACCCGTC ACCCGCGCAT TTTTCCGTTG TATTTCCATG GGGATATGM

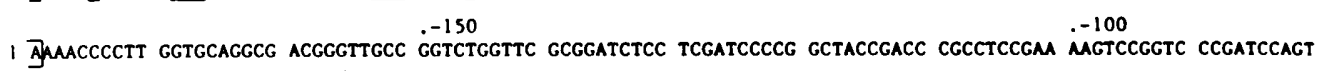

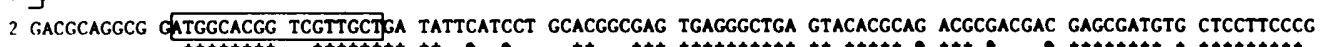

2.

$$
.-50
$$

MET SER SER LEU ARG GLN

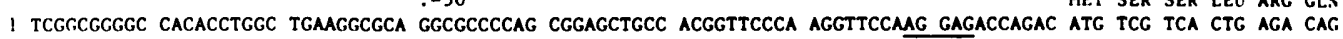

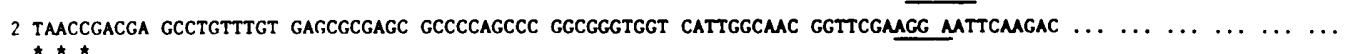

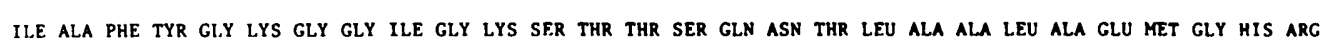
1 ATC GCA TTT TAC GGC AAG GGG GGC ATC GGC AAG TCG ACG ACG TCC CAG MAC ACG CTG GCG GCG CTG GCG GAG ATC GGC CAT CGC

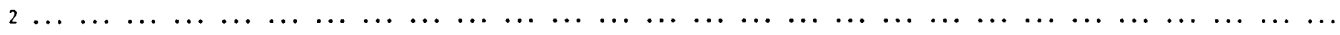
50

II.E LEI II.E VAL GIY CYS ASP PRO LYS ALA ASP SER THR ARG LEU ILE LEU HIS ALA LYS ALA GLN ASP THR ILE LEU SER I.EU 1 ATC CTC ATC GTC GGC TGC GAC CCC AAG GCC GAC TCA ACC CGC CTC ATC CTG CAC GCC MA GCG CAG GAC ACC ATC CTG TCG CTG

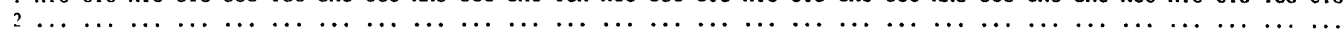

ALA ALA ALA ALA GLY SER VAL GLU ASP LEU GLU LEU GLU GLU VAL MET LYS ILE GLY TYR ARG ASP ILE ARG CYS VAL GLU SER 1 GCC GCC GCC GCC GGC AGC GTC GAA GAC CTC GAG CTC GA GAG GTC ATG AMG ATC GGC TAC CGC GAC ATC CGC TGC GTG GAM TCC

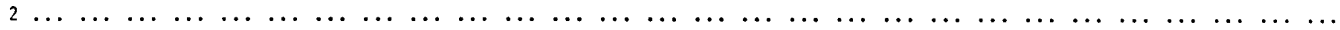

\section{0}

GLY GLY PRO GLU PRO GLY VAL GLY CYS ALA GLY ARG GLY VAL ILE THR SER ILE ASN PHE LEU GLU GLU ASN GLY ALA TYR GLU 1 GGC GGT CCG GAG CCG GGC GTC GGC TGC GCG GGG CGC GGC GTC ATC ACC TCC ATC MAT TTC CTC GAG GAG AAC GGC GCC TAT GAG

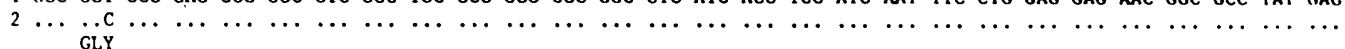

ASP ILE ASP TYR VAL SER TYR ASP VAL LEU GLY ASP VAL VAL CYS GLY GLY PHE ALA MET PRO ILE ARG GLU ASN LYS ALA GLN 1 GAC ATC GAC TAC GTC TCC TAC GAC GTG CTC GGC GAC GTG GTG TGC GGC GGC TTC GCC ATG CCC ATC CGC GAG MAC MAG GCG CAG

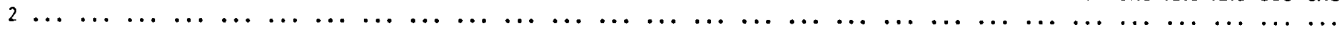

150

GLU ILE TYR ILE VAL MET SER GLY GLU MET MET ALA MET TYR ALA ALA ASN ASN ILE SER LYS GLY ILE LEU LYS TYR ALA ASN 1 GAA ATC TAC ATC GTC ATG TCC GGC GAG ATG ATG GCC ATG TAT GCG GCC MAC AMC ATC TCC AAG GGC ATT CTC MMG TAC GCC MAT

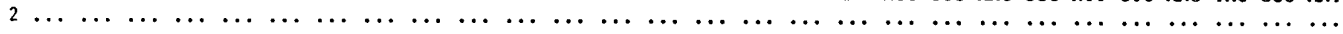
200

SER GLY GLY VAL ARG LEU GLY GLY LEU VAL CYS ASN GLU ARG GLN THR ASP LYS GLU LEU GLU LEU ALA GLU ASN LEU ALA LYS 1 TCC GGC GGC GTG CGC CTG GGC GGG CTC GTC TGC MAC GAG CGC CAG ACG GAC AMG GAG CTG GAA CTG GCC GAG MA CTC GCC MG

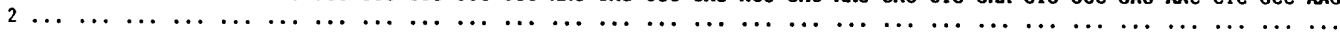

LYS LEU GLY THR GLN LEU ILE TYR PHE VAL PRO ARG ASP ASN ILE VAL GLN HIS ALA GLU LEU ARG ARG MET THR VAL ILE GLU 1 AAG CTC GGC ACC CAG CTC ATC TAT TTC GTG CCG CGC GAC AAC ATC GTC CAG CAC GCC GAG CTG CGC CGC ATG ACG GTG ATC GAG

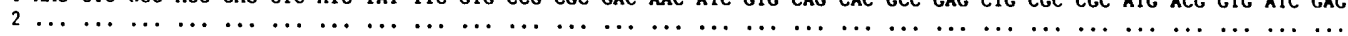
250

TYR ALA PRO ASP SER VAL GLN ALA ASN HIS TYR ARG ASN LEU ALA GLU ARG VAL HIS ASN ASN GLY GLY LYS GLY ILE ILE PRO 1 TAT GCG CCC GAC AGC GTT CAG GCG AAC CAC TAT CGC AAC CTC GCT GAG CGC GTC CAC AAC MT GGC GGC MAG GGC ATC ATC CCG

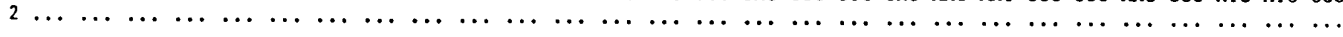

THR PRO ILE THR MET ASP GLU LEU GLU ASP MET LEU MET GLU HIS GLY ILE MET LYS THR VAL ASP GLU SER GLN VAL GLY LYS 1 ACC CCC ATC ACC ATG GAC GAG CTC GAG GAC ATG CTC ATG GAG CAC GGC ATC ATG AAG ACC GTG GAC GAG AGC CAG GTC GGC MG

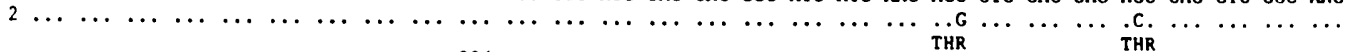

THR ALA ALA GLU LEU ALA ALA LEU SER ALA

1 ACC GCG GCC GAG CTC GCC GCG CTC TCC GCC TGA GCCGACACGC CGGCCGGCCC CCGCGTGGGG CCGGCCTTCG CAACGCAMTG AMGCGAGGA 950

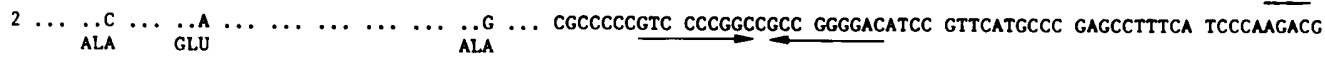

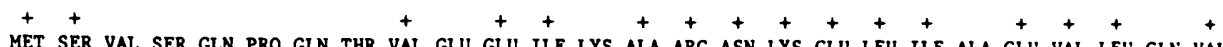
CTT MET SER VAL SER GLN PRO GLN THR VAL GLU GLU ILE LYS ALA ARG ASN LYS GLU LEU ILE ALA GLU VAL LEU GLN VAI. 2 TTTGATTGAG ACT 2 TTTGATTGAG ACCCTTCATT CTGACCGACG ATCCGCGCGA CCGgCCATGG CAGCACACGG CCCAGCCGAT CGCGCGGCCC CCTCAGGCCT GCCGCAGGGC

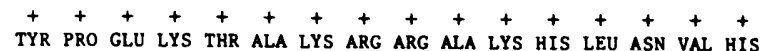

1 TAT CCC GAG AAG ACC GCC AAG CGC CGC GCC AAG CAC CTG AMC GTG CAC 3'

2 ATGCCTCTCA CCGTGTCCTG AagCCGGGag TACACGCCCA TGACCAGCAT GGCCCTGTCT CTGCGACTGC TTCCACGCCT TCCCGGG $3^{\prime}$ 
in Fig. 3. On the basis of amino acid sequence homology with the nifD gene from $B$. japonicum (Kaluza \& Hennecke, 1984), this ORF has been assigned to the ORS571 nifD gene. It is well established that in $K$. pneumoniae nifH is the first gene in a polycistronic operon, followed by nifD, nifK and nifY. A similar arrangement (nifHDK) was found in two fast-growing rhizobia, $R$. meliloti (Ruvkun et al., 1982) and $R$. leguminosarum (Schetgens et al., 1984). In two members of the slow-growing rhizobia, B. japonicum and Rhizobium sp. (Parasponia), nifD and nifK form one operon and $n i f H$ is located elsewhere (Kaluza et al., 1983; Scott et al., 1982). A similar organization (i.e. nifH and nifDK transcribed separately) was found in strain IRc78 which is representative of the tropical cowpea Rhizobium miscellany (Yun \& Szalay, 1984). In the region flanking the $3^{\prime}$ end of ORS571 nifH 1 coding region, an inverted repeat was found 11 nucleotides downstream from the nifHl termination codon (Fig. 3). The mRNA transcribed from this region could potentially form a stem characteristic of a loop terminator structure. The potential stem is formed by 10 consecutive GC pairs. The structure, with a free energy of $\Delta G=$ $-38.2 \mathrm{kcal} \mathrm{mol}^{-1}\left(-159.8 \mathrm{~kJ} \mathrm{~mol}^{-1}\right)$ at $25^{\circ} \mathrm{C}$ as estimated by the method of Tinoco et al. (1973), should be stable. Such a GC-rich inverted repeat structure was already described in $B$. japonicum in the $3^{\prime}$ end flanking region of nifH and nifK, and it was suggested that these sequences could function as transcription terminators (Fuhrmann \& Hennecke, 1984; Thöny et al., 1985). By using Tn5 mutagenesis in the ORS571 nifHDK homologous sequences, we showed that the ORS571 nitrogenase structural genes were organized into a single transcription unit (Denèfle et al., 1987). However, the potential inverted repeat structure preceding nifD might have a regulatory effect on ORS571 nifDK transcription. Similar inverted repeat structures have also been described downstream from each of the nitrogenase structural genes in $A$. vinelandii and in $A$. chroococcum (Brigle et al., 1985; Kennedy et al., 1985). In $A$. vinelandii, the nifHDK genes are part of the same operon (Brigle et al., 1985) and in A. chroococcum, four transcripts were found to hybridize to a nif $H$ probe during nitrogenase derepression (Jones et al., 1984; Kennedy et al., 1985). The size of the transcripts was compatible with a termination near the stop codons of nifH, nifD and nifK within the nifHDK intergenic regions (Kennedy et al., 1985). Thus a transcriptional regulatory function of the inverted repeat structures could not be ruled out.

Nucleotide sequence of nifH2. Computer analysis of the sequenced $1.65 \mathrm{~kb}$ Pst I-SmaI fragment revealed a single ORF large enough to encode a nifH product. Moreover the ORF, which would code for a product of 296 amino acids, shows a high degree of homology, both at the nucleotide and at the amino acid sequence level, with the nifHl coding region. The nucleotide and amino acid sequences of the nifH 2 coding region are shown in Fig. 3. No in-frame ATG was found upstream from the potential start codon at position +1 . Only six nucleotides were changed between $n i f H 1$ and nifH2. Five of these changes affect the third nucleotide of the corresponding codon and have no effect at the amino acid level. The only changed amino acid between the two genes is residue 282, a serine in nifHI and a threonine in nifH2, two amino acids which are chemically related.

Reiterated nifH copies have been found in other $\mathrm{N}_{2}$-fixing organisms. In $C$. pasteurianum (Chen et al., 1986), one of the three nifH sequences that were identified (namely nifHI) encodes a 273 amino acid sequence identical to that determined with the isolated Fe-protein. A second

Fig. 3. Complete nucleotide sequence of Rhizobium ORS571 nifHI and nifH2 coding and flanking regions. The nucleotide sequence of the nifHI non-coding strand is shown in lines with 1 in the margin. In the ORFs, the derived amino acids are printed above the corresponding codons. Numbering of both nucleotides and amino acids starts at the beginning of the nifHl coding sequence. The nucleotide sequence of nifH 2 non-coding strand is shown in lines with 2 in the margin. Nucleotides in the nifH2 coding region identical to nifHI are indicated by dots. Changes in nucleotides or amino acids are mentioned in the text. Downstream from nifHI, the first 42 amino acid residues of nifD are presented. Amino acids identical to the $B$. japonicum nifD gene (Kaluza \& Hennecke, 1984) are indicated by + . Structural features in the nucleotide sequence of nifHI and nifH2 flanking regions are marked as follows: boxed region, consensus nif promoter sequence (Ausubel, 1984); underlined sequences, ribosome-binding site and consensus for upstream activator sequence of nif promoters (Buck et al., 1986); arrows, inverted repeat. *, Nucleotides also found in $B$. japonicum nifH $5^{\prime}$ non-coding region (Fuhrmann \& Hennecke, 1984). 
Table 2. Comparison of regions upstream from ORS571 nifH1 and nifH2 coding sequences with other nif promoters

\begin{tabular}{|c|c|c|}
\hline Origin & Position & Sequence \\
\hline $\begin{array}{l}\text { nif consensus } \dagger \\
\text { K. pneumoniae nifH } \ddagger \\
\text { B. japonicum nifH§ }\end{array}$ & $\begin{array}{c}- \\
-57 \text { to }-41 \\
-178 \text { to }-162\end{array}$ & $\begin{array}{l}\text { 5'-CTGGCACNNNNNTTGCA-3' } \\
\text { 5'-CTGGTATGT T CCCTGCA-3' } \\
\text { 5'-TTGGCACGGC TGTTGCT-3' }\end{array}$ \\
\hline ORS571 nifH1 & -196 to -180 & $5^{\prime}-\stackrel{*}{\mathrm{C}} \stackrel{*}{\mathrm{~T}} \stackrel{*}{\mathrm{G}} \stackrel{*}{\mathrm{C}} \stackrel{*}{\mathrm{~A}} \stackrel{*}{\mathrm{C}} \mathrm{A} \mathrm{CC} \mathrm{CG} \stackrel{*}{*} \mathrm{~T}^{*}{ }^{*} \stackrel{*}{\mathrm{C}} \dot{\mathrm{A}}-3^{\prime}$ \\
\hline ORS571 nifH2 & -169 to -153 & $5^{\prime}-\mathrm{AT}^{*}{ }^{*} \stackrel{*}{\mathrm{G}} \stackrel{*}{\mathrm{C}} \stackrel{*}{\mathrm{C}} \mathrm{GG} \mathrm{T} \mathrm{CG} \stackrel{*}{*}{ }^{*} \mathrm{H}^{*} \mathrm{C} T-3^{\prime}$ \\
\hline
\end{tabular}

† Ausubel (1984). $\quad$ Beynon et al. (1983). § Fuhrmann \& Hennecke (1984).

copy was sequenced and, in the 272 amino acids that it probably encodes, 23 residues differed from the nifHl-encoded Fe-protein. The third nifH-related sequence was found to be less homologous to nifHI and nifH2. On the other hand, the coding regions of the three nifH copies found in R. phaseoli are identical (Quinto et al., 1985).

The flanking regions of the nif 2 coding sequence were determined for about 500 nucleotides upstream from the initiation codon and about 250 nucleotides downstream from the stop codon. A $5^{\prime}$-AGGA-3' potential ribosome binding site was found nine nucleotides upstream from the nifH2 potential start codon. From data reported in Fig. 3, it appeared that nucleotide sequences upstream from nifH $l$ and nifH 2 are different. This situation differs from that found in $R$. phaseoli (Quinto et al., 1985) where the sequences are identical up to nucleotide 96 upstream from the presumptive initiation codon. Beyond, one of the nif $H$ regions diverges while the two others remain identical. The $R$. phaseoli nifH potential transcriptional regulatory signals are located within the region which is conserved upstream from the three nif $H$ genes. In the region downstream from the nifH2 coding sequence (Fig. 3) an inverted repeat structure is located seven nucleotides after the stop codon. A potential stem is formed by nine consecutive basepairs, eight of which are GC pairs. It would be slightly less stable than that found in the case of nifHI. No ORF was detected downstream from nifH2.

Potential promoter regions in the two nifH sequences. The two nifH promoter regions were compared to other known nif promoters and to the nif promoter consensus sequence which was shown to be located $11 \mathrm{bp}$ upstream from the transcription start of nif genes or of other genes subject to $n t r C / n i f A$ control (Ausubel, 1984). Striking similarities with the nif consensus sequence were found, in particular nifHI (Table 2). No sequence reminiscent of a typical E. coli RNA polymerase binding site (5'-TTGACA-N 17 -TATAAT) (Rosenberg \& Court, 1979) was found in either of the two nifH promoter regions. This was in agreement with the fact that nifH, $D$ and $K$ products were not expressed when plasmid pRS2 was introduced into $E$. coli minicells.

The sequences upstream from $K$. pneumoniae nif promoters, which affect nif $A$-mediated activation, contain a $5^{\prime} \mathrm{G}^{\mathrm{A}}-\mathrm{N}_{7}-\mathrm{TGT}-\mathrm{N}_{4}-\mathrm{T}-\mathrm{N}_{5}-\mathrm{ACA}-3^{\prime}$ consensus sequence (Buck et al., 1986). Two regions similar to this consensus were found in the nifH2 promoter region between nucleotides -253 to -238 and between nucleotides -282 to -267 (Fig. 3). In the nifHI promoter region, only the sequence between nucleotides -280 and -265 was identical to the consensus (Fig. 3). However, since no specific deletions were constructed in these sequences, we do not know if they are required for a fully efficient transcription of the nifH gene as was the case in B. japonicum (Alvarez-Morales et al., 1986). It also remains to be determined whether the slight difference between the two ORS571 nifH genes consensus sequences might account for a different regulation of their expression.

The two nifH non-coding regions were compared to the nif $H$ promoters from various rhizobia. Little homology was found to the nifHI non-coding region. However, the nif 22 sequence located downstream from the potential promoter region, between nucleotides -152 and -76 , exhibited 
Table 3. Binary matching coefficients $\left(S_{A B}\right)$ calculated for Rhizobium ORS571 nifHI and nifH from different $N_{2}$-fxing organisms at the DNA and deduced amino acid sequence levels

$S_{\mathrm{AB}}$ for two organisms $\mathrm{A}$ and B was calculated as follows: $S_{\mathrm{AB}}=2 \times$ (no. of identical nucleotides or amino acids between $A$ and $B$ )/[(total no. of nucleotides or amino acids in $A)+($ total no. of nucleotides or amino acids in B)]. References corresponding to the different bacteria are mentioned in the Introduction.

$\quad$ Organism
Anabaena 7120
Klebsiella pneumoniae
Azotobacter vinelandii
A. chroococcum
Rhizobium meliloti
R. phaseoli
R. trifolii
Bradyrhizobium japonicum
Rhizobium sp. (Parasponia)
Clostridium pasteurianum
$\quad$ nifH
nifH2
Methanococcus voltae

\begin{tabular}{cc}
\multicolumn{2}{c}{$\overbrace{\text { Nucleotide sequence }}^{S_{\mathrm{AB}}}$} \\
0.63 & 0.72 \\
0.72 & 0.75 \\
0.72 & 0.73 \\
0.72 & 0.71 \\
0.72 & 0.79 \\
0.74 & 0.80 \\
0.71 & 0.77 \\
0.78 & 0.92 \\
0.80 & 0.93 \\
0.51 & \\
0.50 & 0.61 \\
0.44 & 0.62 \\
& 0.49
\end{tabular}

a strong homology to sequences located downstream from the nif $H$ promoter of $B$. japonicum (Fig. 3) and Rhizobium sp. (Parasponia) (data not shown).

The significance of this conserved region is not yet known. In B. japonicum this presumably untranslated leader region which could potentially form secondary structures is not required for nif $A$-mediated expression of nif $H$ promoter in $E$. coli. (Kaluza et al., 1985). However, it cannot be ruled out that this region is required for optimal nif $H$ expression in the homologous host (Kaluza et al., 1985).

Comparison of amino acid and DNA sequences of nifHI and nifH from other organisms. The sequence of the Fe-protein in ORS571 shows similarities to the Fe-protein sequences from other organisms. In particular, the protein contains the five cysteine residues which are invariant in all species and which are supposed to be involved in the binding of the iron acid-labile sulphur cluster to the apoprotein. The sequence conservation is particularly clustered around the cysteine residues and in the $\mathrm{N}$-terminal region which, according to Robson (1984), might contribute to an adenine-nucleotide-binding domain. Based on the nucleotide and amino acid sequences, similarity coefficients $\left(S_{\mathrm{AB}}\right)$ (Fox et al., 1977) were calculated between the ORS571 nifHI gene and other nifH genes (Table 3). The highest degree of homology was found with two members of the slow-growing rhizobia, Rhizobium sp. (Parasponia) and B. japonicum. It was previously suggested that nif $H$ genes and $16 \mathrm{~S}$ rRNA within a given bacterium may have evolved in parallel (Hennecke et al., 1985). Moreover, from analysis of both 16S rRNA and nifH homology between rhizobia it was found that fast- and slow-growing rhizobia fall into two groups (Hennecke et al., 1985). Based on nifH $S_{\mathrm{AB}}$ comparison, it appears that ORS571 is much more related to rhizobia belonging to the slow growers, in agreement with taxonomic studies.

In ORS571, nitrogenase is subject to 'switch-off' which, as in photosynthetic bacteria, results from a specific inactivation of the Fe-protein (Kush et al., 1985). This phenomenon, which was discovered with free-living bacteria, was also observed in bacteroids (this laboratory, unpublished). In Rhodospirillum rubrum, inactivation was shown to be due to a covalent modification of the Fe-protein. The modifying group is adenosine diphosphoribose linked through the terminal ribose to a guanidino nitrogen of arginine. The modified site in the protein is Gly-Arg(ADP-ribose)-Gly-Val-Ile-Thr (Pope et al., 1985). This amino acid sequence, which is located around residues 100 and 106 , is highly conserved in all nif $H$ products whose sequence has been established or deduced from the nucleotide sequence, with the exception of Anabaena 7120 (Mevarech et al., 1980) and C. pasteurianum (Chen et al., 1986) where Val is replaced by Ile. In 
Table 4. Codon usage in the ORS571 nifH gene

\begin{tabular}{|c|c|c|}
\hline \multicolumn{2}{|c|}{$\begin{array}{l}\text { Residue and } \\
\text { codon }\end{array}$} & $\begin{array}{l}\text { No. of } \\
\text { codons }\end{array}$ \\
\hline Phe & $\begin{array}{l}\text { UUU } \\
\text { UUC }\end{array}$ & $\begin{array}{l}1 \\
3\end{array}$ \\
\hline Leu & $\begin{array}{l}\text { UUA } \\
\text { UUG } \\
\text { CUU } \\
\text { CUC } \\
\text { CUA } \\
\text { CUG }\end{array}$ & $\begin{array}{r}0 \\
0 \\
0 \\
15 \\
0 \\
11\end{array}$ \\
\hline Ile & $\begin{array}{l}\text { AUU } \\
\text { AUC } \\
\text { AUA }\end{array}$ & $\begin{array}{r}1 \\
22 \\
0\end{array}$ \\
\hline Met & AUG & 13 \\
\hline Val & $\begin{array}{l}\text { GUU } \\
\text { GUC } \\
\text { GUA } \\
\text { GUG }\end{array}$ & $\begin{array}{r}1 \\
10 \\
0 \\
9\end{array}$ \\
\hline Ser & $\begin{array}{l}\text { UCU } \\
\text { UCC } \\
\text { UCA } \\
\text { UCG } \\
\text { AGU } \\
\text { AGC }\end{array}$ & $\begin{array}{l}0 \\
8 \\
2 \\
3 \\
0 \\
3\end{array}$ \\
\hline
\end{tabular}

$\begin{array}{cc}\begin{array}{c}\text { Residue and } \\ \text { codon }\end{array} & \begin{array}{c}\text { No. of } \\ \text { codons }\end{array} \\ \text { Pro CCU } & 0 \\ \text { CCC } & 4 \\ \text { CCA } & 0 \\ \text { CCG } & 4 \\ \text { Thr ACU } & 0 \\ \text { ACC } & 8 \\ \text { ACA } & 0 \\ \text { ACG } & 5 \\ \text { Ala GCU } & 1 \\ \text { GCC } & 17 \\ \text { GCA } & 1 \\ \text { GCG } & 11 \\ \text { Tyr UAU } & 5 \\ \text { UAC } & 6 \\ \text { His CAU } & 1 \\ \text { CAC } & 5 \\ \text { Gln CAA } & 0 \\ \text { CAG } & 9 \\ \text { Asn AAU } & 3 \\ \text { AAC } & 11\end{array}$

Residue and No. of

Lys AAA 0

AAG $\quad 14$

Asp GAU 0

GAC 15

Glu GAA 5

GAG 20

Cys UGU 0

UGC 5

Trp UGG 0

Arg CGU 0

CGC 13

CGA $\quad 0$

CGG 0

AGA 1

AGG 0

Gly GGU $\quad 1$

GGC 26

GGA $\quad 0$

GGG 3

Total 296

ORS571 nifHI and nifH2 products, the Gly-Arg-Gly-Val-Ile-Thr sequence is found between residues 101 and 107 (Fig. 3). Although some features of the 'switch off/on' phenomenon in ORS571 seemed to be different from that observed in photosynthetic bacteria (Kush et al., 1985), it is possible that Arg in position 102 is the site of the 'switch-off' modification.

$G+C$ content and codon usage in ORS571 nifH genes. Codon usage in ORS571 nifH genes is very biased (Table 4). Four amino acids are coded by a single coding triplet (glutamine, lysine, aspartate and cysteine). An asymmetrical codon usage occurs for isoleucine, glutamate, arginine and glycine. In total, 21 of the 60 coding triplets are not used. The absence of tryptophan, which is another feature of most nifH genes, should be noted. The $\mathrm{G}+\mathrm{C}$ content in the nifH coding region is $64 \%$ and a very high $\mathrm{G}+\mathrm{C}$ content was found in the third position of codons, $92 \%$ as compared to $61 \%$ in the first position and to $39 \%$ in the second. This probably reflects the high $\mathrm{G}+\mathrm{C}$ content of the ORS571 genome, which is 66\% (Dreyfus, 1982).

\section{Functional analysis of the two nifH copies}

We previously reported that nifHI deletion mutant 57182 had a $\mathrm{Nif}^{+} \mathrm{Nod}^{+} \mathrm{Fix}^{+}$phenotype (Denèfle et al., 1987). The plasmid used to construct this mutant was pRS82 (Fig. 1) in which the two $X$ hoI fragments carrying nifHl were replaced by a $\mathrm{Km}^{\mathrm{R}}$ cartridge from $\mathrm{Tn} 5$. It is likely that in pRS82 the nifDK transcription is initiated from the $\mathrm{Km}^{\mathrm{R}}$ gene promoter. The $\mathrm{Nif}^{+} \mathrm{Fix}^{+}$ phenotype of mutant 57182 led us to conclude that a second copy of nifH was functional (Denèfle et al., 1987). However, we had no proof that this second nifH gene was the nifH2 copy detected by hybridization and studied here. Thus, it was of interest to obtain both a nifH2 mutant and a double nifHI-nifH2 mutant.

Table 5 indicates the procedure followed to obtain strain 57171 that carries a deletion of nif $H 2$ and strain 57172 that carries a double nifH1-nifH2 deletion. The method, similar to that described by Ruvkun \& Ausubel (1981), was based on the incompatibility between pRK 290 and pPH1JI and between pLA29-17 and R751. It was checked by hybridization that deletions in strains 57171 and 57172 had occurred at the correct location (data not shown). The mutants were used to inoculate Sesbania rostrata plantlets. Nitrogenase activity both ex planta and in planta

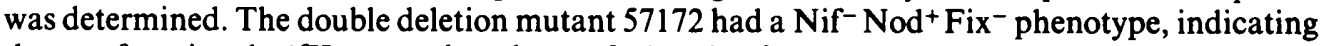
that no functional nifH gene other than nifHI and nifH2 was present in ORS571. Moreover, 
Table 5. Site-directed mutagenesis of the two nifH copies

Selection was performed on minimal LSN solid medium (Elmerich et al., 1982), containing appropriate antibiotics: gentamicin $(\mathrm{Gm}), 10 \mu \mathrm{g} \mathrm{ml}^{-1}$; kanamycin $(\mathrm{Km}), 100 \mu \mathrm{g} \mathrm{ml}^{-1}$; spectinomycin $(\mathrm{Sp})$, $50 \mu \mathrm{g} \mathrm{ml}^{-1}$; tetracycline (Tc), $10 \mu \mathrm{g} \mathrm{ml}^{-1}$; trimethoprim (Tp), $400 \mu \mathrm{g} \mathrm{ml}^{-1}$.

\begin{tabular}{|c|c|c|c|c|}
\hline Donor strain & Recipient strain & $\begin{array}{l}\text { Selected } \\
\text { marker }\end{array}$ & Frequency & $\begin{array}{l}\text { Designation of } \\
\text { selected strain }\end{array}$ \\
\hline $\begin{array}{l}\text { HB101(pRK 2013) } \\
\mathrm{MCl061(pRS71)}\end{array}$ & ORS571 & Tc--Sp & $10^{-2}$ & ORS571(pRS71) \\
\hline HB101(R751) & ORS571(pRS71) & $\begin{array}{l}\text { Tp } \\
T p-S p \\
\left.\left(100 \% T_{c}\right)^{5}\right) \\
T p-T c\end{array}$ & $\begin{array}{l}10^{-3} \\
10^{-7} \\
10^{-9}\end{array}$ & $57171^{*}$ \\
\hline $\begin{array}{l}\mathrm{HB} 101 \text { (pRK2013) } \\
\text { MC1061 (pRS82) }\end{array}$ & 57171 & $\mathrm{Tc}-\mathrm{Sp}$ & $10^{-8}$ & $57171(\mathrm{pRS} 82)$ \\
\hline HB101 (pPH1JI) & $\begin{array}{l}57171 \text { (pRS82) } \\
\text { train } 57171 \text { conta } \\
\text { train } 57172 \text { conta }\end{array}$ & $\begin{array}{l}\mathrm{Gm}-\mathrm{Km} \\
\text { ains plasmid } \\
\text { ains plasmid }\end{array}$ & $\begin{array}{l}10^{-7} \\
1 . \\
1 \mathrm{JI} .\end{array}$ & $57172 \dagger$ \\
\hline
\end{tabular}

strains 57171 and 57182 had a nitrogenase specific activity ex planta which was $70 \%$ and $30 \%$, respectively, of that observed with the wild-type strain. This could suggest that in the wild-type strain nifHl accounts for about $70 \%$ of $\mathrm{N}_{2}$ fixation ex planta and nif $\mathrm{H} 2$ for $30 \%$, in agreement with the value of $30 \%$ of ORS571 total nitrogenase activity assigned to the nif 22 gene that was previously calculated from data obtained with crude extracts of mutant 57182 (Denèfle et al., 1987). An unexpected result was the divergence obtained in planta, since the nitrogenase specific activity of strain 57182 was about $80 \%$, whereas with strain 57171 the nitrogenase activity was only $15 \%$ and the inoculated plantlets looked in poor condition. As the amino acid sequences of the two nifH genes deduced from the nucleotide sequences are almost identical, it is likely that the two Fe-proteins have similar specific activities. Two hypotheses could account for this observation: (i) the deletion in strain 57171 might have a polar effect on the transcription of a $f x$ gene located downstream; (ii) the expression of the two nifH genes might be slightly different $e x$ planta and in planta. The first hypothesis seems unlikely since the entire $1.65 \mathrm{~kb}$ Pst I-SmaI fragment, deleted in strain 57171, was sequenced and no other ORF was detected downstream from nifH2. In $R$. phaseoli, it was shown that at least two of the three nifH genes can be functionally expressed (Quinto et al., 1985). In Rps. capsulata only one nifH gene is functional in the wild-type strain but a second copy can be activated when the first one is mutated (Scolnik \& Haselkorn, 1984). In $A$. chroococcum, the second nifH copy was transcribed under molybdenum deficiency conditions (Robson et al., 1986). The significance of these reiterated $n i f H$ sequences whether functional or not under defined physiological conditions is not yet known but their existence raises a puzzling and interesting question which might be solved by further investigations based, in particular, on the study of nifH-lac $Z$ fusions.

The authors wish to thank Dr J.-P. Aubert for discussions, Dr D. Dean for reading the manuscript, Dr R. Deblaere for the gift of pGV764, Ms N. Desnoues and A. Paquelin for skilful technical assistance, and the personnel of the Centre d'Informatique Scientifique at the Pasteur Institute for computer facilities. This work was supported by a grant (no. GBI-5-028F) from the Commission of the European Communities and by research funds from the University Paris 7.

\section{REFERENCES}

Allen, L. L. \& Hanson, R. S. (1985). Construction of broad-host-range-cosmid cloning vectors: identification of genes necessary for growth of Methylobacterium organophilum on methanol. Journal of Bacteriology 161, 955-962.
Alvarez-Morales, A., Betancourt-Alvarez, M., Kaluza, K. \& HenNecke, H. (1986). Activation of the Bradyrhizobium japonicum nifH and nifDK operons is dependent on promoter-upstream DNA sequences. Nucleic Acids Research 14, 4207-4227. 
AusubEL, F. M. (1984). Regulation of nitrogen fixation genes. Cell 37, 5-6.

Beynon, J. L., Cannon, M., Buchanan-Wollaston, V. \& Cannon, F. M. (1983). The nif promoters of Klebsiella pneumoniae have a characteristic primary structure. Cell 34, 665-671.

Brigle, K. E., Newton, W. E. \& Dean, D. R. (1985). Complete nucleotide sequence of the Azotobacter vinelandii nitrogenase structural gene cluster. Gene 37, 37-44.

Buck, M., Miller, S., Drummond, M. \& Dixon, R. (1986). Upstream activator sequences are present in the promoters of nitrogen fixation genes. Nature, London 320, 374-378.

Casadaban, M., Chou, J. \& Cohen, S. (1980). In vitro gene fusions that join an enzymatically active $\beta$ galactosidase segment to amino-terminal fragments of exogenous proteins: Escherichia coli plasmid vectors for the detection and cloning of translational initiation signals. Journal of Bacteriology 143, 971980.

Chen, K. C. K., Chen, J. S. \& Johnson, J. L. (1986). Structural features of multiple nifH-like sequences and very biased codon usage in nitrogenase genes of Clostridium pasteurianum. Journal of Bacteriology 166, 162-172.

Denèfle, P., Kush, A., Norel, F., Paquelin, A. \& Elmerich, C. (1987). Biochemical and genetic analysis of the nifHDKE region of Rhizobium ORS571. Molecular and General Genetics 206, (in the Press).

Donald, R. G. K., Nees, D. W., Raymond, C. K., LOROCH, A. I. \& LUDWIG, R. A. (1986). Characterization of three genomic loci encoding Rhizobium sp. strain ORS571 $\mathrm{N}_{2}$ fixation genes. Journal of Bacteriology 165, 72-81.

Downie, J. A., MA, Q. S., KNIGHT, C. D., НомBRECHER, G. \& JOHNSTON, A. W. B. (1983). Cloning of the symbiotic region of Rhizobium leguminosarum: the nodulation genes are between the nitrogenase genes and a nifA like gene. EMBO Journal 2, 947952.

DREYfus, B. L. (1982). La symbiose entre Rhizobium et Sesbania rostrata, légumineuse à nodules caulinaires. Doctorat-ès-Sciences thesis, University of Paris 7.

DREYFUS, B. L. \& DOMMERGUES, Y. R. (1981). Nitrogen-fixing nodules induced by Rhizobium on the stem nodules of the tropical legume Sesbania rostrata. FEMS Microbiology Letters 10, 313-317.

DReYfus, B. L., Elmerich, C. \& DOMMergues, Y. R. (1983). Free-living Rhizobium strain able to grow on $\mathrm{N}_{2}$ as sole nitrogen source. Applied and Environmental Microbiology 45, 711-713.

EADY, R. \& Smith, B. E. (1979). Physico-chemical properties of nitrogenase and its components. In $A$ Treatise on Dinitrogen Fixation, sections I and II, pp. 765-798. Edited by R. W. F. Hardy, F. Bottomley \& R. C. Burns. New York: Wiley.

Elmerich, C., Houmard, J., Sibold, L., Manheimer, I. \& Charpin, N. (1978). Genetic and biochemical analysis of mutants induced by bacteriophage $\mathrm{Mu}$ DNA integration into Klebsiella pneumoniae nitrogen fixation genes. Molecular and General Genetics 165 , $181-189$.

Elmerich, C., Dreyfus, B. L., Reysset, G. \& Aubert, J.-P. (1982). Genetic analysis of nitrogen fixation in a fast-growing Rhizobium. EMBO Journal 1, 499503.

EMERICH, D. W. \& BurRIS, R. H. (1978). Complementary functioning of the component proteins of nitrogenase from several bacteria. Journal of Bacteriology 134, 936-943.

FIGURSKI, D. H. \& HeLINSKI, D. R. (1979). Replication of an origin-containing derivative of plasmid RK2 dependent on a plasmid function provided in trans. Proceedings of the National Academy of Sciences of the United States of America 76, 1648-1652.

Fox, G. E., Pechmann, K. R. \& Woese, C. R. (1977). Comparative cataloguing of 16S rRNA; molecular approach to prokaryotic systematics. International Journal of Systematic Bacteriology 27, 44-57.

Fuhrmann, M. \& HenneCKe, H. (1984). Rhizobium japonicum nitrogenase Fe protein gene (nifH). Journal of Bacteriology 158, 1005-1011.

HaSe, T., WaKabaYashi, S., NaKane, T., ZumfT, W. G. \& Matsubara, H. (1984). Structural homologies between the amino acid sequence of Clostridium pasteurianum MoFe-protein and the DNA sequences of nifD and nifK genes of phylogenetically diverse bacteria. FEBS Letters 166, 39-43.

Hausinger, R. P. \& Howard, J. B. (1982). The amino acid sequence of the nitrogenase iron protein from Azotobacter vinelandii. Journal of Biological Chemistry 257, 2483-2490.

HeNNECKE, H. (1981). Recombinant plasmids carrying nitrogen fixation genes of Rhizobium japonicum. Nature, London 291, 354-355.

HENNECKE, H., Binder, F. \& GUNTHER, I. (1982). A novel cloning vector for the direct selection of recombinant DNA in Escherichia coli. Gene 19, 231234.

Hennecke, H., Kaluza, K., Thony, B., Fuhrmann, M., LudWIG, W. \& StackebrandT, E. (1985). Concurrent evolution of nitrogenase genes and $16 \mathrm{~S}$ rRNA in Rhizobium species and other nitrogenfixing bacteria. Archives for Microbiology 142, 342348.

HiRsCh, P. R. \& Beringer, J. E. (1984). A physical map of pPH1JI and pJB4JI. Plasmid 12, 139-141.

JobaNPUTRA, R. S. \& DATTA, N. (1974). Trimethoprim $\mathbf{R}$ factors in enterobacteria from clinical specimens. Journal of Medical Microbiology 7, 169-178.

JoNES, R., WoOdLEY, P. \& RoBson, R. (1984). Cloning and organization of some genes for nitrogen fixation from Azotobacter chroococcum and their expression in Klebsiella pneumoniae. Molecular and General Genetics 197, 318-327.

Kallas, T., Rebiere, M. C., Rippka, R. \& Tandeau DE MARSAC, N. (1983). The structural nif genes of the cyanobacteria Gloeothece $\mathrm{sp}$. and Calothrix sp. share homology with those of Anabaena sp. but the Gloeothece genes have a different arrangement. Journal of Bacteriology 155, 427-431.

Kaluza, K., Fuhrmann, M., Hahn, M., RegensBURGER, B. \& HENNECKE, H. (1983). In Rhizobium japonicum the nitrogenase genes nifH and nifDK are separated. Journal of Bacteriology 155, 915-918.

KaluZA, K. \& HenNeCKe, H. (1984). Fine structure analysis of the nifDK operon encoding the $\alpha$ and $\beta$ subunits of dinitrogenase from Rhizobium japonicum. Molecular and General Genetics 196, 35-42.

Kaluza, K., Morales, A. A. \& Hennecke, H. (1985). 
Oligonucleotide directed mutagenesis of the Rhizobium japonicum nifH promoter. FEBS Letters 188, 37-42.

Kennedy, C., Robson, R., Jones, R., WoOdley, P., Evans, D., Bishop, P., Eady, R., Gamal, R., Humphrey, R., Ramos, J., Dean, D., Brigle, K., Toukdarian, A. \& Postgate, J. (1985). Genetic and physical characterization of nif and ntr genes in Azotobacter chroococcum and A. vinelandii. In Nitrogen Fixation Research Progress, pp. 469-476. Edited by H. J. Evans, P. J. Bottomley \& W. E. Newton. Dordrecht \& Boston: M. Nijhoff.

Kush, A., Elmerich, C. \& AUbert, J.-P. (1985). Nitrogenase of Sesbania Rhizobium strain ORS571: purification, properties, and 'switch-off' by ammonia. Journal of General Microbiology 131, 1765-1777.

Maniatis, T., Fritsch, E. F. \& Sambrook, J. (1982). Molecular Cloning: a Laboratory Manual. Cold Spring Harbor, NY: Cold Spring Harbor Laboratory.

Mazur, B. J., Rice, D. \& Haselkorn, R. (1980) Identification of blue-green algal nitrogen fixation genes by using heterologous DNA hybridization probes. Proceedings of the National Academy of Sciences of the United States of America 77, 186190.

Merrick, M., Filser, M., Kennedy, C. \& Dixon, R. (1978). Polarity of mutations induced by insertion of transposons $\operatorname{Tn} 5, \operatorname{Tn} 7$ and $\operatorname{Tn} 10$ into the nif gene cluster of Klebsiella pneumoniae. Molecular and General Genetics 165, 103-111.

Messing, J. \& Vieira, J. (1982). A new pair of M13 vectors for selecting either DNA strand of doubledigest restriction fragments. Gene 19, 269-276.

Mevarech, M., Rice, D. \& Haselkorn, R. (1980). Nucleotide sequence of a cyanobacterial nifH gene coding for nitrogenase reductase. Proceedings of the National Academy of Sciences of the United States of America 77, 6476-6480.

Norel, F., Desnoues, N. \& Elmerich, C. (1985a). Characterization of DNA sequences homologous to Klebsiella pneumoniae nif $H, D, K$ and $E$ in the tropical Rhizobium ORS571. Molecular and General Genetics 199, 352-356.

Norel, F., Kush, A., Denèfle, P., Salzano, G. \& ELMERICH, C. $(1985 b)$. Genetic analysis in Sesbania Rhizobium ORS571. In Nitrogen Fixation Research Progress, p. 140 . Edited by E. J. Evans, P. J. Bottomley \& W. E. Newton. Dordrecht \& Boston: M. Nijhoff.

Pope, M. R., Murrell, S. A. \& Ludden, P. W. (1985). Covalent modification of the iron protein of nitrogenase from Rhodospirillum rubrum by adenosine diphosphoribosylation of a specific arginine residue. Proceedings of the National Academy of Sciences of the United States of America 82, 3173-3177.

Prakash, R. K. \& AtHerly, A. G. (1984). Reiteration of genes involved in symbiotic nitrogen fixation by fast-growing Rhizobium japonicum. Journal of Bacteriology 160, 785-787.

Quinto, C., De la Vega, H., Flores, M., Fernandez, L., Balado, T., Soberon, G. \& Palacios, R. (1982). Reiteration of nitrogen fixation gene sequences in Rhizobium phaseoli. Nature, London 22, 724726 .
Quinto, C., De la Vega, H., Flores, M., Leemans, J., Cevallos, M. A., Pardo, M. A., Azpiroz, R., De lourdes Girard, M., Calva, E. \& Palacios, R. (1985). Nitrogenase reductase: a functional multigene family in Rhizobium phaseoli. Proceedings of the National Academy of Sciences of the United States of America 82, 1170-1174.

Rice, D., Mazur, B. J. \& Haselkorn, R. (1982). Isolation and physical mapping of nitrogen fixation genes from the cyanobacterium Anabaena 7120. Journal of Biological Chemistry 257, 13157-13163.

ROBSON, R. (1984). Identification of possible adenine nucleotide-binding sites in nitrogenase $\mathrm{Fe}$ - and MoFe-proteins by amino acid sequence comparison. FEBS Letters 173, 394-398.

RoBson, R., WoOdLEY, P. \& JoNEs, R. (1986). Second gene (nifH*) coding for a nitrogenase iron protein in Azotobacter chroococcum is adjacent to a gene coding for a ferredoxin-like protein. EMBO Journal 5, 1159 1163.

ROSENBERG, M. \& COURT, D. (1979). Regulatory sequences involved in the promotion and termination of RNA transcription. Annual Review of Genetics 13, 319-353.

Ruvkun, G. B. \& Ausubel, F. M. (1980). Interspecies homology of nitrogenase genes. Proceedings of the National Academy of Sciences of the United States of America 77, 191-195.

Ruvkun, G. B. \& Ausubel, F. M. (1981). A general method for site directed mutagenesis in prokaryotes: construction of mutations in symbiotic nitrogen fixation genes of Rhizobium meliloti. Nature, London 289, 85-89.

Ruvkun, G. B., Sundaresan, V. \& Ausubel, F. M. (1982). Directed transposon Tn5 mutagenesis and complementation analysis of Rhizobium meliloti symbiotic nitrogen fixation genes. Cell 29, 551-559.

SANGer, F., Nicklen, S. \& Coulson, A. R. (1977). DNA sequencing with chain terminating inhibitors. Proceedings of the National Academy of Sciences of the United States of America 74, 5463-5467.

Schetgens, T. M. P., Bakkeren, G., van Dun, C., Hontelez, J. G., van Kammen, A. \& Van Den Bos, R. C. (1984). Identification and analysis of the expression of Rhizobium leguminosarum symbiotic genes. In Advances in Nitrogen Fixation Research, p. 699. Edited by C. Veeger and W. E. Newton. The Hague: M. Nijhoff \& Dr W. Junk.

SCOLNIK, P. A. \& HASELKoRn, R. (1984). Activation of extra copies of genes coding for nitrogenase in Rhodopseudomonas capsulata. Nature, London 307 , 289-292.

Scott, K. F., Rolfe, B. G. \& Shine, J. (1981). Biological nitrogen fixation: primary structure of the Klebsiella pneumoniae nifH and nifD genes. Journal of Molecular and Applied Genetics 1, 71-81.

Scott, K. F., Hugues, J. E., Gresshoff, P. M., Beringer, J. E., Rolfe, B. G. \& Shine, J. (1982). Molecular cloning of Rhizobium trifolii genes involved in symbiotic nitrogen fixation. Journal of Molecular and Applied Genetics 1, 315-326.

ScotT, K. F., Rolfe, B. G. \& SHINE, J. (1983a). Nitrogenase structural genes are unlinked in the non-legume symbiont Parasponia Rhizobium. DNA 2, 141-148. 
Scott, K. F., Rolfe, B. G. \& Shine, J. (1983b). Biological nitrogen fixation: primary structure of the Rhizobium trifolii iron protein gene. DNA 2, 149-155.

Shine, J. \& Dalgarno, L. (1974). The 3'-terminal sequence of Escherichia coli $16 \mathrm{~S}$ ribosomal RNA: complementarity to nonsense triplets and ribosome binding sites. Proceedings of the National Academy of Sciences of the United States of America 71, 13421346.

Staden, R. (1983). Computer methods for DNA sequencers. In DNA Sequencing, pp. 311-368. Edited by J. Hindley, T. S. Worth \& R. H. Bividon. Amsterdam: Elsevier Biochemical Press.

Souillard, N. \& SibOLD, L. (1986). Primary structure and expression of a gene homologous to $n i f H$ (nitrogenase $\mathrm{Fe}$-protein) from the archaebacterium Methanococcus voltae. Molecular and General Genetics 203, 21-28.

Sundaresan, V. \& Ausubel, F. M. (1981). Nucleotide sequence of the gene coding for the nitrogenase iron protein from Klebsiella pneumoniae. Journal of Biological Chemistry 256, 2808-2812.

Tanaka, M., Haniu, M., Yasunobu, T. \& Mortenson, L. (1977). The amino acid sequence of Clostridium pasteurianum iron protein, a component of nitrogenase. Journal of Biological Chemistry 252, 7093-7100.
Thony, B., Kaluza, K. \& Hennecke, H. (1985). Structural and functional homology between the $\alpha$ and $\beta$ subunits of the nitrogenase MoFe-protein as revealed by sequencing the Rhizobium japonicum nifK gene. Molecular and General Genetics 198, 441-448. TINOCO, J., Borer, P. N., Dengler, B., LeVINE, M. D., Uhlenbeck, O. C., Crothers, D. M. \& Gralla, J. (1973). Improved estimation of secondary structure in ribonucleic acid. Nature, London 246, 40-41.

TOROK, I. \& KondOROSI, A. (1981). Nucleotide sequence of the $R$. meliloti nitrogenase reductase (nifH) gene. Nucleic Acids Research 21, 5711-5723.

VieIRA, J. \& MESSING, J. (1982). The pUC plasmids, an M13mp7-derived system for insertion mutagenesis and sequencing with synthetic universal primers. Gene 19, 259-268.

Wain-Hobson, S., Sonigo, P., Danos, O., Cole, S. \& Alizon, M. (1985). Nucleotide sequence of the AIDS virus. LAV. Cell 40, 9-17.

Yun, A. C. \& Szalay, A. A. (1984). Structural genes of dinitrogenase and dinitrogenase reductase are transcribed from two separate promoters in the broad host range cowpea Rhizobium strain IRc78. Proceedings of the National Academy of Sciences of the United States of America 81, 7358-7362. 